\title{
The sound pattern of Standard Italian, as compared with the varieties spoken in Florence, Milan and Rome
}

Pier Marco Bertinetto

Scuola Normale Superiore, Pisa bertinetto@sns.it

Michele Loporcaro

Romanisches Seminar, Universität Zürich loporcar@rom.unizh.ch

This paper is a condensed presentation of the phonetics and phonology of Standard Italian, compared to the most prestigious local accents, viz. those of Florence, Milan and Rome. Historically based on the Florentine pronunciation, and traditionally identified with it, Standard Italian is nowadays used by trained speakers such as stage actors and (but less and less so) radio and TV speakers. The present paper aims at depicting the most salient features of Standard Italian, still a matter of primary reference in language courses, comparing them with the characteristic features of the three most prominent local varieties, with which the foreign learner is most likely to be confronted. All traditional (and sometimes widely debated) issues of Italian phonetics/phonology are addressed in the most ecumenical setting possible.

Italian is a Romance language spoken by about 60 million people in the Italian peninsula. It also is one of the official languages of the Swiss Confederation, in which it is spoken natively by some 300,000 people in the Canton Tessin and in the four South Western valleys of Canton Graubünden. A small minority of Italian speakers (a few thousand) is still to be found in Istria (Republics of Croatia and Slovenia), where the Italian-speaking population dropped dramatically after the displacement of political boundaries following World War II (cf. Metzeltin 1992: 320). In Malta, Italian is the third language, after Maltese and English, although it lost official status in 1964 (cf. Cassola 1992: 870f.). Italian is also used, at different levels of proficiency, in expatriate immigrant communities in several parts of the world (Coveri \& Bettoni 1991).

Standard Italian (henceforth SI) is written in the Latin alphabet; extant written records of Italo-Romance varieties date back to the 9th century. Today's SI is based on the Tuscan (more precisely Florentine) dialect, for which extensive documentation is available from the second half of the 13th century. From this dialect, SI inherited its phoneme inventory, but not all allophonic processes. This Florentine-based variety reached the status of an official variety, shared by educated people all over Italy for administrative and literary purposes between the 14 th and the early 16th century. Italian, however, did not become the language of everyday communication in all social classes until the 20th century (De Mauro 1972). It is nowadays 
spoken with distinct local accents (cf. Canepari 1979, 1980, 1999 for a comprehensive survey). Among these, the Roman and the Milanese varieties are especially prominent owing to their use in the media, alongside the Florentine variety, which is very close to SI. Over the past few decades especially the Milanese accent seems to be increasingly gaining prestige (Galli de' Paratesi 1985). Thus, although our sketch basically centres on SI, we will introduce a number of remarks on the three above-mentioned local varieties of Italian (henceforth RI, MI and FI), considering that SI is nowadays part of the active verbal repertoire of just a minority of educated people from Central Italy (especially Tuscany), besides being used by professional speakers or trained stage actors (the single idiolects spoken by these groups of people may, however, include sporadic features typical of RI). Due to its cultural, social and political relevance, the definition of (the status of) SI has been the topic of a long-lasting debate. Besides De Mauro (1972) see, for a recent summary, Marazzini (1994).

Note that many of the features to be described in what follows are not only characteristic of each of the three urban varieties considered, but rather spread over a wider area, namely Northern (MI) and Central-Southern Italy (RI), or Tuscany (FI). The reader should however refrain from assuming that our description tacitly characterises the relevant (inter-)regional domains. A detailed analysis of the non-negligible local differences would far exceed the scope of the present paper.

Within Romance, Italian is one of the most conservative languages with respect to its source (Latin), especially at the phonetic level. On the other hand, vernacular Romance varieties (i.e. primary dialects) spoken in Northern and Southern Italy are highly innovative, often diverging from each other as dramatically as Spanish does from Portuguese or Catalan (cf. Rohlfs 1966-69, Maiden \& Parry 1997 for a survey, and Pellegrini 1977 for the reference chart of Italian vernaculars). Italo-Romance vernaculars will not be directly addressed here, but only sporadically mentioned for their substratum influence on the respective local varieties of the national language. Within the verbal repertoire of linguistic communities in Italy, vernaculars and local varieties of Italian coexist, with the latter historically resulting from the superposition of the Florentine-based literary language (eventually giving rise to contemporary SI) on the former (Pellegrini 1960, Berruto 1987).

\section{Consonants}

The consonant table contains symbols of only phonemically contrasting units, but arranges them in columns corresponding to phonetic points of articulation. (We agree with Walter Belardi that the denomination 'place of articulation', although generally accepted, is somewhat infelicitous. What is actually meant is 'place of constriction' or luogo diaframmatico in Belardi's terminology.) Actually, only four places of articulation are distinctive in Italian, since the following are not mutually contrastive: bilabial and labiodental, dental and alveolar,

\begin{tabular}{|c|c|c|c|c|c|c|c|c|}
\hline & Bilabial & $\begin{array}{l}\text { Labio- } \\
\text { dental }\end{array}$ & Dental & Alveolar & $\begin{array}{l}\text { Post- } \\
\text { alveolar }\end{array}$ & Palatal & Velar & $\begin{array}{l}\text { Labial- } \\
\text { velar }\end{array}$ \\
\hline Plosive & $\mathrm{p} \quad \mathrm{b}$ & & $\mathrm{t} \quad \mathrm{d}$ & & & & k $\quad \mathrm{g}$ & \\
\hline Affricate & & & ts $\quad \overline{d z}$ & & $\widehat{d} \sqrt{3}$ & & & \\
\hline Nasal & $\mathrm{m}$ & & & $\mathrm{n}$ & & $\mathrm{n}$ & & \\
\hline Trill & & & & $\mathrm{r}$ & & & & \\
\hline Fricative & & f $\quad v$ & s $\quad \mathrm{Z}$ & & $\int(3)$ & & & \\
\hline Approximant & & & & & & $\mathrm{j}$ & & w \\
\hline $\begin{array}{l}\text { Lateral } \\
\text { approximant }\end{array}$ & & & & 1 & & $\kappa$ & & \\
\hline
\end{tabular}


postalveolar and palatal. The following list of (sub)minimal pairs exemplifies the fundamental contrasts:

pari ['pa:ri] 'even' vs. Bari ['ba:ri] 'place name'; tino ['timo] 'vat' vs. Dino ['dimo] (a personal name); cola ['korla] 'percolate.3sg' vs. gola ['gorla] 'throat';

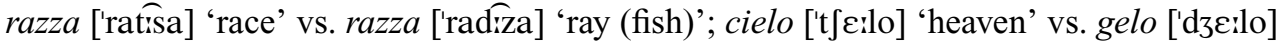
'frost';

lama ['la:ma] 'blade' vs. lana ['la:na] 'wool' vs. lagna ['lan:a] 'querulous complaint'; para ['paira] 'para rubber' vs. pala ['pa:la] 'shovel' vs. paglia ['paKia] 'straw'; scafo ['skaifo] 'hull' vs. scavo ['skaivo] 'excavation'; fuso ['fuiso] 'spindle' vs. fuso ['fuizo] 'melted.m.sg' vs. uscio ['u[:o] 'door'

(as for the approximants, see below in the section concerning diphthongs).

Plosives are unaspirated in all positions. When clustering with dental obstruents, alveolar sonorants (except /r/) become dental: dentro ['dentro] 'inside', scalzo ['skaltso] 'barefoot'. Besides [r], which is the unmarked allophone of the rhotic phoneme, individual variants may be encountered (uvular, alveolar or labio-dental approximant; uvular trill). In intervocalic position, non-geminated [r] may often reduce in spontaneous speech to a single linguo-palatal contact; however, after pause or before a consonant, there is usually a double contact.

The phoneme $/ z /$ has a limited distribution. It contrasts with/s/ only intervocalically within or at the right edge of lexical morphemes (e.g. SI, but also FI and RI, ['fuiso] 'spindle' vs. ['fuizo] 'fused', both spelled fuso, where /z/ occurs before the inflectional morpheme), but not morpheme- and word-initially, where only /s/ occurs before vowels (e.g. sale ['sa:le] 'salt'), and the voicing contrast is neutralised before a consonant due to assimilation (see below). As for $/ 3 /$, it appears in brackets in the table because it occurs only marginally in loanwords, in intervocalic position: abat-jour [aba'zur] 'table lamp', garage [ga'ra3] 'garage'.

Word-initially, MI neutralises the contrast /ts/ vs. $/ \hat{\mathrm{dz}} /$ in favour of the latter. Besides, the articulation of $/ \widehat{t} \int \widehat{d} \widehat{s} \mathrm{n} /$ is slightly more anterior than in SI, to the extent that - at the lower end of the sociolinguistic continuum $-/ \kappa \mathrm{n} /$ may be realised as [lj nj] (Mioni 2001: 162). Intervocalic /s/ is voiceless in RI, so that SI minimal pairs, such as ['kjerse] 'asked.3sg' vs. ['kje:ze] 'churches' (both spelled chiese), are neutralised as ['kjeise] in RI. On the other hand, the growing influence of the Northern pronunciation on FI has levelled out some traditional contrasts, such as the one cited, so that ['kje:ze] is now increasingly accepted in both meanings, although normative pronunciation treatises still record the contrast. In MI, the same pair is neutralised into ['kjeize] (for the different vowel, see below) for another reason, since in this variety (as opposed to RI) voiceless intervocalic [s] does not occur morpheme-internally, but only after vowel-final prefixes (e.g. risollevare [risol:e'va:re] 'to raise again'), unless the prefix is no longer synchronically analysed as such (e.g. risaltare [rizal'taire] 'to stand out'). This behaviour at morphological boundaries is basically found in all Northern varieties, although a fair amount of idiolectal variation is to be observed (Bertinetto 1999b, Baroni 2001).

There has been a lively debate in classical phonemics (summarised in Muljačić 1972: 62-70; see also Loporcaro 1996) addressing the status of geminates as either 'mono-' or 'biphonemic' units. We use here the term 'geminate', as is customary in the contemporary phonological literature, to denote phonetically long (rather than rearticulated, as in e.g. French ne coupe pas [nø kup 'pa]) consonants, phonologically parsed into two subsequent syllables. Italian has 15 contrastive geminate consonants: e.g. callo ['kal:o] 'corn (i.e. epidermal hardening)' vs. calo ['ka:lo] 'lower.1sg', fatto ['fat'o] 'deed' vs. fato ['fa:to] 'fate', caccio ['kat:jo] 'hunt.1sg' vs. cacio ['ka:t]o] 'cheese'. These occur intervocalically (as in the examples just mentioned) or before glides, e.g. occhiali [o'k:jarli] 'spectacles', assieme [a'sije:me] 'together', commuovere [ko'miworvere] 'to move (psych.)', annientare [an:jen'ta:re] 'annihilate', arruolare [ar:wo'la:re] 'enrol'. In addition, a subset of geminate obstruents consisting of oral stops and /f/ may precede laterals and trills so that the second part of the geminate forms a complex onset: accludere [a'k:lurdere] 'to enclose', afflitto [a'f:lit:o] 
'sorrowful', attrezzo [a'trretiso] 'tool', offro ['of:ro] 'offer.1sg', agglomerato [agilome'raito] 'agglomerate', abbreviare [abire'vja:re] 'to shorten', raddrizzare [radiri'tisarre] 'to straighten'. (Clusters with $/ \mathrm{vl} /$, found only in loan words, may undergo postlexical gemination as a consequence of 'raddoppiamento fonosintattico' (see below): $a$ [v:]ladimiro 'to Vladimir'.) The fricative / $\mathrm{z} /$ does not occur as geminate, owing to its restricted distribution (see above), nor do the glides $/ \mathrm{j}$ w/. However, /j/ is always long in RI: e.g. maiale RI [ma'jaa:le] 'pig'.

Also excluded from the gemination correlation are the phonemes $/ \mathrm{n} \kappa \int \mathrm{ts} \mathrm{dz} /$, for they tend to have geminate-like duration, most saliently in intervocalic position: cf. ragno ['ran:o] 'spider', aglio ['aא:o] 'garlic', ascia ['a]:a] 'axe', organizzazione [organid:za'tisjo:ne] 'organisation' (one partial exception is $g l i[\kappa(\mathrm{i}) \mathrm{i}]$, allomorph of the m.pl. definite article, with optional degemination in FI, even when it occurs in intervocalic position). This class is singled out by traditional labels such as 'consonanti rafforzate' ('strengthened consonants') or 'geminate intrinseche' ('intrinsic geminates'). Historically these consonants evolved from clusters and/or geminates (e.g. paglia ['paאia] 'straw' $<*$ ['palija] $<$ Lat. ['palea $\left.^{\mathrm{m}}\right]$ ) and patterned like true geminates in the context of phonological processes. For instance, they

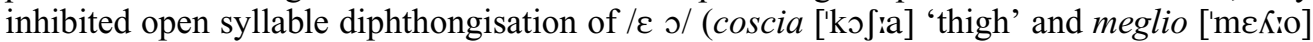
'better', like cotta ['kot:a] 'cooked.f.sg' and bello ['belı] 'beautiful.m.sg', vs. cuoca ['kworka] 'cook.f.sg' and miete ['mje:te] 'harvest.3sg'. Further evidence for their historical ambisyllabic status is provided by the preservation of the masculine definite article $l o$, that was not ousted by the innovative allomorph $i l$ before word-initial 'intrinsic' geminates, e.g. lo sciocco [lo 'frok:o], lo gnomo [lo 'n:ormo], lo zoccolo [lo 'tisokiolo], lo zero [lo 'dize:ro], 'the idiot, gnome, hoof, zero' vs. il sale [il 'sa:le] 'the salt', il naso [il 'na:so] 'the nose'.

From these examples, one distributional peculiarity of 'intrinsic' geminates stands out: unlike distinctive geminates, they are permitted word-initially, provided they are followed by a vowel, although the examples with $/ \kappa \mathrm{n} /$ are fairly rare, in particular with $/ \kappa /$. The section on phonotactics will address further distributional constraints bearing on intrinsic geminates. The only word beginning with a distinctive geminate in SI and FI is (di) Dio ['d'io] '(of) God' (owing to historical agglutination of the definite article: il Dio > (I)ddio; we mark this lengthening with a semichrone, conforming to our recording); in RI, a few more items may be quoted, namely: chiesa ['kije:sa] 'church', sedia ['sic:dja] 'chair', là ['lia] 'there', qua, qui ['kiwa], ['kiwi] 'here', merda ['m:crda] 'shit' (the phonetic manifestation of gemination presupposes that these words are preceded by a vowel in connected speech, as in di Dio 'of God'). Although contrastive word-initial geminates are cross-linguistically rare (cf. e.g. Abramson 1986, Hume et al. 1997), they notably occur in some Central and Southern Italo-Romance vernaculars. RI displays this feature due to substratum influence from one such variety (Romanesco). For contrastive initial geminates in other Southern Italo-Romance vernaculars, see Bertinetto \& Loporcaro (1999), Romano (2003).

Acoustically, it should be noted that the behaviour of [ $\mathrm{n} K$ ] (in terms of intrinsic duration and shortening effect on the previous stressed vowel) seems to be somewhat less geminate-like than that of contrastive obstruent geminates (Endo \& Bertinetto 1999, Celata \& Kaeppeli, to appear). In Northern varieties, including MI, the consonants in the [n $\left.\Lambda \int \widehat{\mathrm{ts}} \widehat{\mathrm{dz}}\right]$ set that are more liable to occur as phonetic geminates are [ $\widehat{\mathrm{ts}} \widehat{\mathrm{dz}}]$. Note, however, that Northern speakers tend to have an orthography-driven pronunciation, so that they may present a length opposition in vizi ['vi:tsi] 'vices' vs. vizzi ['vitîsi] 'withered.m.pl'. But since Northern vernaculars lack consonant quantity (and often present vowel quantity instead), the realisation of all geminate consonants is in general less consistent in MI than in the remaining varieties considered here. Still at the level of phonetic manifestation, it should also be noted that $\left[K_{\mathrm{i}}\right]$ is often realised as [j:] in non-acrolectal RI.

Concerning the main allophonic processes, /s/ assimilates for voice to following consonants: svelto ['zvelto] 'quick', smemorato [zmemo'ra:to] 'forgetful' vs. stanco ['stajko] 'tired', while nasals categorically assimilate for place to following consonants (glides excluded): canto ['kanto] 'sing.1sg', anfora ['amfora] 'amphora', fango ['fango] 'mud', conscio ['kon $\left.{ }^{\mathrm{j}} \mathrm{o}\right]$ 'aware'. The latter process applies postlexically as evidenced by external 
sandhi contexts: con Carlo [kon 'karlo] 'with Charles', in vetta [im 'vetra] 'on the top', in barca [im 'barka] 'on (the) boat'. In FI and RI, word-final nasals, especially in function words, may fully assimilate to word-initial sonorants: in mente [i 'msente] 'in (one's) mind', un ramo [u 'rra:mo] 'a branch', un lago [u 'la:go] 'a lake' (in the recording, however, the RI speaker had a hyperarticulated pronunciation with [in 'mente], while the FI speaker produced [un 'ra:mo] and [ũ 'la:go]). In MI, by contrast, one often finds [ $\mathrm{\eta}$ ] generalised in coda position, except before [t d $\widehat{\mathrm{ts}} \mathrm{dz}]$, although actual performance fluctuates somewhat.

A phonological process of sandhi gemination of word-initial consonants (known as 'raddoppiamento/rafforzamento fonosintattico') applies after final stressed vowels when no pause intervenes: e.g. tre case [,tre 'kaase] 'three houses', parlò latino [par'lo lia'tino] 's/he spoke Latin'. Raddoppiamento is also triggered by a small set of weak monosyllables and paroxytones ('irregular' raddoppiamento), as a remnant of the sandhi-assimilation of an etymological final consonant from which this process originated: $a$ te [a 't:e] 'to you', come voi ['ko'me 'v:oi] 'like you.pl'. Raddoppiamento applies vacuously when the wordinitial consonant is $/ \int \mathrm{n} \kappa \widehat{\mathrm{ts}} \widehat{\mathrm{dz}} /$, for in the context relevant to Raddoppiamento (namely, intervocalically) the named consonants geminate independently. On the other hand, it does not apply with initial $/ \mathrm{j}$ w/, nor with initial $/ \mathrm{S} /+\mathrm{C}$ clusters (where capital $\mathrm{S}$ indicates voicing neutralisation): tre spari [tre 'sparri] 'three shots'. By contrast, all other initial clusters regularly undergo raddoppiamento: tre treni [tre 'trre:ni] 'three trains', tre chiavi [tre 'kija:vi] 'three keys', with the exception of the obstruent + obstruent/nasal clusters only occurring in loan words from Greek: cf. [ps] psicologia 'psychology', [kn] Cnosso 'Cnossus', [pn] pneumatico 'tyre', [pt] pterodattilo 'pterodactyl', [ft] ftalico 'phthalic' (the first consonant of these words tends, however, to have a somewhat longer duration even in non-Raddoppiamento contexts). Raddoppiamento also applies in RI and FI, which present both stress-conditioned and 'irregular' raddoppiamento, although with minor lexical divergencies (e.g. da te 'from you', SI and FI [da 't:e] vs. RI [da 'te]). Most Central and Southern varieties only possess the latter type of raddoppiamento, although with a lexical distribution that varies from place to place (Loporcaro 1997). By contrast, raddoppiamento is unknown in MI, as in all Northern varieties. Raddoppiamento has attracted much attention in the phonological literature over the past few decades; see Absalom et al. (2004) for a recent overview.

In-depth consideration of regional variation in allophonic processes would require a lengthy monograph. Just to mention some of the most remarkable phenomena, RI (along with several varieties spoken south of Tuscany) shows affrication of $/ \mathrm{s} /$ after dental/alveolar sonorants: e.g. penso RI ['pentso] vs. SI ['pennso] 'think.1sg', col sole RI [kol 'tsorle] vs. SI [kol 'so:le] 'with the sun', corsa RI ['kortsa] vs. SI ['korsa] 'race'. As for Tuscany, this feature has only lately made its timid appearance in the pronunciation of younger FI speakers, despite being widely attested in other parts of the same region (cf. Castellani 1993). FI and RI also display deaffrication of intervocalic /t $\mathrm{f} /$ (cf. pace ['pa: $\left.\int \mathrm{e}\right]$ 'peace', la cena [la ' e:na] 'the dinner' as opposed to SI pasce ['pa [:e] 'pasture.3sg', la scena [la 'ficna] 'the scene'; cf. Migliorini 1954), although the deaffricated allophone may have an approximantlike articulation or, as among the young generation of RI speakers, may present velarisation (cf. Canepari 1999: 93, 430). Limited to FI, this process also affects intervocalic $/ \widehat{\mathrm{d}}$ /: agio

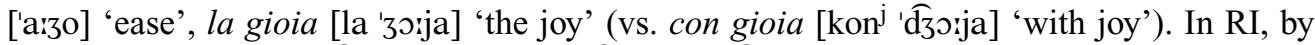

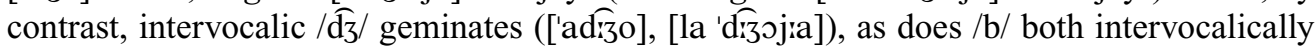
and before glide or liquid (cubo ['kubro] 'cube', la birra [la 'brira] 'the beer', la bietola [la 'b:je:tola] 'the beetroot', libro ['lib:ro] 'book'; note that a preceding off-glide behaves like a vowel in this respect: sai bene [sai 'bic:ne] '(you) know well'). A prominent feature of FI pronunciation is the spirantisation of intervocalic voiceless stops (the so called 'gorgia toscana') which, mostly limited to $/ \mathrm{k} /$, breaks into educated pronunciation: e.g. coca-cola [,korha 'həsla] 'coke' (as for its variable phonetic implementation, see Sorianello 2003). In RI, non-geminated voiceless stops are lenited intervocalically (or before glide and liquid; here again, a preceding off-glide behaves like a vowel) resulting in voiceless (or slightly voiced) lenis stops: hai capito [ai g̊a'birdo] 'you have understood', i quadri [i 'g̊wa:dri] 'the pictures', 
litro ['lisdoro] 'litre'. The process may also variably affect fricatives: e.g. ripòsati [ri'bo:zadi] 'take a rest'.

As for the palatalisation process that played such an important role in shaping Italian

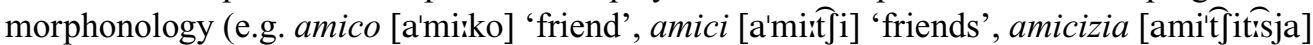
'friendship'), this is no longer productive, and its morpholexical distribution is not predictable except before a few derivational affixes.

\section{Vowels}

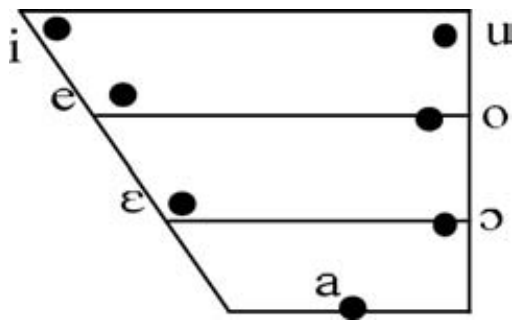

In stressed syllables, Italian has seven monophthongal vowel phonemes, shown in the vowel chart and exemplified in the following list of minimal pairs (Lepschy 1964: 55, Muljačić 1972: 42):

pizzo ['piťso] 'lace' vs. pezzo ['pețso] 'piece' vs. pazzo ['patiso] 'crazy.m.sg' vs. pozzo ['pot̂so] 'pit' vs. puzzo ['putiso] 'stench';

botte ['bot:e] 'barrel' vs. botte ['bot:e] 'blows (pl.)';

venti ['venti] 'twenty' vs. venti ['venti] 'winds'.

As for their formant values, Ferrero et al. (1978) provide the mean figures as in table 1, based on the production of isolated disyllables of the type $/{ }^{\prime} \mathrm{CV}_{\mathrm{x}} \mathrm{C}_{\mathrm{d}} \mathrm{V}_{\mathrm{x}} /$ by 10 Florentine students, where $C_{d}$ stands for a voiced or voiceless dental stop. (Ferrero 1972 provides similar figures, relating to isolated vowels uttered by 50 speakers, half for each gender, of miscellaneous regional origin).

Stressed vowels are lengthened in word-internal open syllables when they occur at the end of the intonational phrase (thus including isolated words) or under emphasis: cf. casa ['karsa] 'house' vs. cassa ['kasia] 'chest' and casetta [ka'seta] 'little house'. Contrary to wide-spread opinion, this lengthening process is thus far from being a categorical word-level phenomenon, as observed in Bertinetto (1981), Landi \& Savy (1996) and McCrary (2003), and as confirmed in the corpus-based study carried out by Dell'Aglio et al. (2002). The exact phonetic implementation of the stress-conditioned lengthening process is, in any case, prosodically governed even at the word level (Marotta 1985). Thus, although we mark lengthening in our transcriptions, even within stretches of connected speech, this merely indicates the pronunciation appropriate to isolated words. (Occasionally, however, we use a raised dot to

Table 1 Average formant values of SI vowels.

\begin{tabular}{|c|c|c|c|c|c|c|c}
\cline { 2 - 8 } \multicolumn{1}{c|}{} & $\mathrm{i}$ & $\mathrm{e}$ & $\varepsilon$ & $\mathrm{a}$ & o & o & u \\
\hline F1 & $290 \pm 35$ & $350 \pm 45$ & $490 \pm 50$ & $780 \pm 45$ & $550 \pm 40$ & $390 \pm 60$ & $320 \pm 40$ \\
\hline F2 & $2310 \pm 140$ & $2050 \pm 110$ & $1950 \pm 100$ & $1430 \pm 80$ & $970 \pm 40$ & $870 \pm 80$ & $800 \pm 100$ \\
\hline F3 & $2960 \pm 165$ & $2590 \pm 100$ & $2600 \pm 80$ & $2490 \pm 110$ & $2650 \pm 160$ & $2430 \pm 160$ & $2270 \pm 140$ \\
\hline
\end{tabular}


mark different degrees of lengthening, either to suggest tendential destressing in vowels, or because of performance idiosyncrasies affecting geminates, as witnessed by the recordings.) As for MI (as well as, in general, all regional accents from Northern Italy), it is characterised by tendential lack of vowel lengthening in proparoxytones (cf. tavolo ['tavolo] 'table').

A notable feature is the lack of lengthening of word-final stressed vowels. In this position, all vowel phonemes occur except /o/: cf. città [ $\mathfrak{t}$ [i'tra] 'city', però [pe'ro] 'however', caffè [ka'f:c] 'coffee', perché [per'ke] 'because', virtù [vir'tu] 'virtue', fini [fi'ni] '(s/he) ended'. Final stressed /o/ only occurs in the pronunciation of foreign names such as Bordeaux; however, the corresponding loan word, indicating a nuance of red, has been adapted as [bor'do], often spelled bordò. The same lowering historically applied to no [no] 'no' (instead of the expected $*[$ no] from Lat. NŌN).

Since vowel duration is contextually conditioned in the relevant environments, as indicated above, Italian has no phonological vowel quantity. Even the occasional reiteration of the same vowel at morpheme boundaries is pronounced as a quickly rearticulated vowel (at least with respect to the prosodic profile), rather than as a single long vowel, e.g. cooperare 'cooperate', linee 'lines', zoologia 'zoology' (with both vowels unstressed) and zóo 'zoo', finii 'finished.1sg', lineétta 'little line', piissimo 'very pious' (with stress on one of the two vowels; stress marks do not correspond to orthography here). Indeed, in allegro style (especially when both vowels are unstressed), the two vowels may be reduced to a single short one.

As for regional variation, the distribution of stressed higher- vs. lower-mid vowels, both front and back, diverges in FI, RI and MI. In FI and RI, where these phonological contrasts are fairly pervasive, one may observe a number of mismatches in lexical distribution, even though the latter varieties are rather close to SI in this respect, e.g. FI lettera ['let'era] 'letter', scendo ['Jendo] 'go down.1sg', storpio ['storpjo] 'cripple', colonna [ko'lonia] 'column' vs. RI $l[\mathrm{e}]$ ttera, $s c[\varepsilon] n d o, s t[\mathrm{o}] r p i o, c o l[0] n n a$. SI accepts each variant except for the last (cf. Camilli \& Fiorelli 1965: 157-164). As for MI, /e $\varepsilon /$ tend to be in complementary distribution, so that this contrast does not have an overwhelming phonemic relevance, while /o o/ have by and large the same distribution as in SI, despite occasional divergencies. However, the latter vowels differ less among each other than in the other varieties considered here, for [0] is actually pronounced slightly higher, namely [?] (on the other hand, stressed /o/ is definitely [o] in RI).

A detailed description of the state of affairs in MI is to be found in Poggi Salani (1976). Suffice it to say that /e/ (often realised as [e] ) tends to occur in non-final open syllables and before nasals, except when these are geminated (Canepari 1999: 379; cf. $v[\varepsilon] n n e$ in line 1 of the MI tale recording, reported in the appendix): see MI cielo ['t Terlo] 'heaven', penso ['pẹjso] 'think.1sg' (realised as ['pẹnso] in our recording), bene ['bẹ:ne] 'well' (note that SI presents $/ \varepsilon /$ in all of these cases); / $/ \varepsilon /$, by contrast (actually lowered to $[\varepsilon]$ ), tends to occur in closed syllables and word-finally in open syllables: MI bicicletta [bit $j i$ 'kle̦tia] 'bicycle', verde ['vęrde] 'green', te ['tॄ]] 'you', as opposed to SI, FI and RI bicicl[e]tta, $v[\mathrm{e}] r d e, t[\mathrm{e}]$. In any case, the opposition /e $\varepsilon /$ retains a marginal phonemic value even in MI, for these vowels occasionally contrast in the same environments: e.g. $r e$ ['rę] 'king' vs. $r e$ ['rẹ] 'D (musical note)', with reversal of the SI, FI and RI opposition. Besides, not all closed syllables involve $\mid \varepsilon /:$ for instance, /e/ is retained when the final vowel of an infinitive is truncated before a clitic (vederlo [ve'derrlo] 'to see it'), and regularly occurs before /gi/ (e.g. leggo ['legro] 'read.1sg'). Moreover, one regularly finds / $\varepsilon /$ in hiatus before /i/ (e.g. nei ['nع̨ii] 'moles').

In non-final unstressed position, only five vowels occur, namely [i e a o u]. Lower-mid vowels do not occur, as they merge with higher-mid through raising: cf. legge ['ledize] 'read.3sg' vs. legge ['ledize] 'law', neutralised in leggiamo [le'dizarmo] 'read.1pl', leggina [le'dizina] 'little law'; foro ['forro] 'forum' vs. foro ['fo:ro] 'hole', neutralised in forense [fo'rense] 'forensic', forato [fo'ra:to] 'pierced'. These unstressed allophones are usually somewhat intermediate, i.e. [ẹ o], although in our transcriptions we ignore this detail. Castellani (1956: 55-58) has an in-depth discussion of the varying heights of unstressed /e o/. The height of these 
vowels is context-sensitive, depending on adjacent consonants as well as on vowels in adjacent syllables. For instance, unstressed /e/ is more open in terrestre [tẹ'ricstre] 'terrestrial', due to the following $/ \mathrm{r} /$ and to stressed $/ \varepsilon /$, than in retino [re'ti:no] 'little net', due to the following high vowel; similarly, the /e/ in the second syllable is slightly more closed in credere ['kre:dere] 'to believe' than in crederci ['kre:dert $\widehat{\text { Ti] }}$ 'to believe in (something)'.

While raising applies to both inflected and derived forms, it does not apply to the first element of a compound, which retains secondary (lexical) stress (see also below): appendiabiti [a,p:endi'a:biti] 'dress-hanger' (cf. appendo [a'p:cndo] 'hang.1sg' vs. appendiamo [apren'dja:mo] 'hang.1pl'), tossicodipendente [,tosiikodipen'dente] 'drug-addict' (cf. tossico ['tossiko] 'toxic' vs. intossicare [intosii'ka:re] 'intoxicate'). In words like beneficio [bene'fiit]o] 'benefit', the first element (originally $b[\varepsilon$ : $] n e$ 'well') behaves phonologically like a prefix rather than like the first member of a compound. In general, the likelihood for raising to affect the stressed vowel of the first stem in a compound increases with the increase of morpho-semantic opacity: thus portafoglio [porta'foK:o] 'wallet', copriletto [,kopri'letio] 'bedspread' (lit. 'bring-paper' and 'bed-cover') may as well be pronounced [porta'foK:o], [kopri'letro], which correlates with the (semantic) fact that they are, respectively, not a mere 'sheet of paper (foglio) holder' nor a generic 'bed-covering device'. Furthermore, a prosodic factor comes into play here, as raising is less likely to occur as the stress interval grows, thus diminishing the likelihood of destressing of the first member of the compound. Consequently, portamonete 'wallet' and copridivano 'sofa-cover' (as opposed to portafoglio, copriletto) never display raising, because of both their morpho-semantic transparency and the longer stress interval. On the other hand, so-called 'classical compounds', consisting of two bound morphemes, optionally allow raising, as the morphological structure of these complex words is now completely opaque to the average speaker: glottologia [glotiolo'dzira]/[glot:olo'dziia] 'glottology',

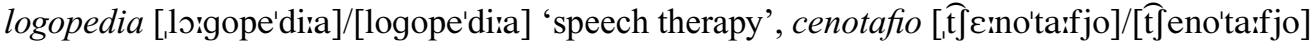
'cenotaph'. In a few cases, the opposite process, i.e. lowering, may be observed under suffixation, e.g. Platone [pla'tome] 'Plato' vs. platonico [pla'tonniko] 'Platonic', protone [pro'tome] 'proton' vs. protonico [pro'tonniko] 'protonic', censore [ $\mathrm{t}$ ]en'sorre] 'censor' vs. censorio [ $\widehat{\mathrm{t}}$ ]en'sorrio] 'censorial', direttore [dire'tiorre] 'director' vs. direttorio [dire'trorrio] 'directory' (cf. Nespor 1993: 94, who, however, includes examples like poeta 'poet' vs. poetico 'poetic', profeta 'prophet' vs. profetico 'prophetic', which actually exhibit stressed $\mid \varepsilon /$ in all alternants of the root). Historically in all of these (learned) words the lowermid vowel used to occur, which was however modified in the base, due to analogical leveling on the model of -one, -ore suffixes in directly inherited words. Raising in derivation is to be observed in Malesia [ma'le:zja] 'Malesia' vs. malese [ma'lerse] 'Malay'.

Word-finally, there are only four unstressed vowel phonemes, due to the non-occurrence of $/ \mathrm{u} /$, except for a few loanwords, such as bantu ['bantu]. Such loanwords, indeed, were often adapted through stress-shift: cf. the alternative form bantù [ban'tu] as well as tabù [ta'bu] 'taboo' (the latter in common use as opposed to tabu ['ta:bu], confined to the ethnologists' jargon).

Italian has the opening and the closing diphthongs as shown in table 2 (cf. Muljačić 1972: 85ff., Mioni 2001: 176-180). (We use 'opening' and 'closing' as referring to the position of the glide, before or after the syllabic peak.)

Table 2 Opening and closing diphthongs of Sl.

\begin{tabular}{|c|c|c|c|c|c|c|c|}
\hline syllabic V & $\mathrm{i}$ & $\mathrm{e}$ & $\varepsilon$ & a & 0 & o & $\mathrm{u}$ \\
\hline raising with [i] & & je & $\mathrm{j} \varepsilon$ & ja & jo & jo & ju \\
\hline raising with [w] & wi & we & we & wa & wo & wo & \\
\hline falling with [i] & & ei & $\varepsilon \dot{~}$ & ai & oi & oi & ui \\
\hline falling with $[\mathrm{u}]$ & & $\mathrm{eu}$ & $\varepsilon \mathrm{u}$ & $\mathrm{au}$ & & & \\
\hline
\end{tabular}


Most of the observed gaps have a straightforward phonetic (articulatory / perceptual) explanation, as they would create universally disfavoured strings (e.g. */ji/, */wu/, */ii/, $* /$ uu/). In opening diphthongs actual glides occur, although the constriction is not particularly notable, so that these phones retain a relatively vocalic flavour, despite their consonant-like behaviour in distributional terms:

soffietto [so'frjet:o] 'bellows' (stressed /je/ mostly occurs in closed syllables), pieno ['pje:no] 'full', chiave ['kja:ve] 'key', pianta ['pjanta] 'plant', chiodo ['kjordo] 'nail', fiore ['fjorre] 'flower', biondo ['bjondo] 'blond', piuma ['pjurma] 'feather' (/jo/ occurs only exceptionally in closed syllables, as in tiorba ['tjorba] 'theorbo');

guida ['gwidda] 'guide', quindi ['kwindi] 'hence', quello ['kwelı] 'this', querimonia [kweri'monia] 'complaint', quercia ['kwert]a] 'oak', querulo ['kwe:rulo] 'querulous', guado ['gwa:do] 'ford', quando ['kwando] 'when', quota ['kworta] 'quota', acquoso [a'kiworso] 'watery' (/wo/, /wo/ are rare in closed syllables)

True semivowels are found in closing dipththongs: potei [po'tei] 'could.1sg', sei [sci] 'six', baita ['baita] 'mountain hut', poi ['poi] 'later', voi ['voi] 'you.pl', lui ['lui] 'he', pleurite [pleu'ritte] 'pleuritis', neutro ['neutro] 'neutre', auto ['auto] 'car'.

Triphthongs arise from a sequence of two onglides, normally separated by a morpheme boundary, plus a vowel: e.g. continuiamo [konti'nuja:mo] 'continue.1pl' (where the labialpalatal glide $[\mathrm{y}]$ is due to coarticulation). Triphthongs within lexical morphemes are much rarer (cf. acquiescenza [akiwje'f: $\varepsilon$ tsa] 'acquiescence'), although they may surface in allegro style: quiete [kwi'e:te] $\rightarrow$ ['kwje:te] 'calmness'. (The glide in the last two words may possibly be [u], as in contin [ $\mathrm{Y}]$ iamo, at least for some speakers. No one, however, has carried out a detailed investigation to date.)

In general, unstressed /i u/ in hiatus can turn into glides in allegro speech: e.g. biennale [bie'n:a:le] $\rightarrow$ [bje'naa:le] 'biennial'. This is all the more likely, the further the stress from the affected syllable: attualizzare [at:uali'd:za:re] $\rightarrow$ [at:wali'diza:re] 'to update', but biennio 'biennium' does not become *['bjen:jo]. This process also affects the creation of closing diphthongs from word-final / Vi/ strings, which are normally realised as hiatus before pause: e.g. poi ['pori]/['poi] 'later on', lui ['luii]/['lui] 'he'. In fast speech even mid-vowels may become semivowels, as in allegro speech stereotipato [stereoti'pa:to] $\rightarrow$ [stereoti'pa:to] 'stereotyped' or coalizione [koali'tisjome] $\rightarrow$ [koali'tisjo:ne] 'coalition'. Lexically stressed vowels may become glides when they are contextually destressed, especially when they occur in function words: e.g. il mio/tuo libro [il 'mi'o/'tu'o 'lisbro] $\rightarrow$ [il mjo/two 'libbro] 'my/your book'. In most cases, however, stress is a reliable criterion to distinguish between hiatus and diphthong (cf. Laura ['laurra] (person name) vs. paura [pa'urra] 'fear', faida ['faida] 'feud' vs. faina [fa'ina] 'stone-marten'). On other occasions the difference may be very subtle in connected speech: cf. chiosa ['kjozza] 'gloss' vs. chi osa [,ki 'o:za] 'who dares'.

In connected speech, word-final unstressed vowels are often weakened prevocalically, and this can result in various degrees of reduction, from glide formation (buoni amici ['bwornj a'mi: $\widehat{i} \mathrm{i}]$ 'good friends') to complete deletion (gli amici arrivano [ $\Lambda$ a'mi: $\widehat{t}$ a'riivano] 'the friends arrive'). Indeed, many function words exhibit a prevocalic allomorph: cf. [lo], [la]/[1] 'def.art.m., f.sg'; [uno], [una]/[un] 'indef.art.m., f.sg'; [delı], [delia]/[del:] 'of the.m., f.sg', etc. (in spelling, this grammaticalised elision is marked by an apostrophe, e.g. l', un', dell', etc., except for un 'indef.art.m.sg'). More generally, as word-boundaries have no phonological import in the language, a string such as - 'V\#\#V - may be realised as a closing diphthong, e.g. proprietà inalienabile [proprie'ta inalje'na:bile] 'inalienable property', paltò amaranto [pal'to ama'ranto] 'amaranth coat'. The actual implementation is subject to massive variation; in any case, the insertion of a glottal stop between the abutting vowels would only emerge in strongly hyperarticulated, emphatic speech (Camilli \& Fiorelli 1965: 63-69, 83-87; Marotta \& Sorianello 1998; Canepari 1999: 94-96, 143-148; Mioni 2001: 209ff.). 
On the other hand, the rhythmically based process of post-sonorant final unstressed vowel deletion (known as 'troncamento'), which used to be fairly widespread, is now severely restricted. A few lexicalised allomorphs (buon, bel, quel) still testify to the wide range of application in past stages of the language: un buon $\left(*^{*}\right.$ ) consiglio [um 'bwon kon'siא:o] 'a good suggestion', quel $(* l o)$ giorno [,kwel 'dु3orno] 'that day', bel (*lo) cane [,bel 'ka:ne] 'beautiful dog'. These exceptions aside, the only vowel liable to be elided in contemporary SI is /e/. This process is mandatory only in sequences of infinitives plus enclitics ( finir $\left({ }^{*} e\right)$ lo 'to finish it', condur (*re)ci 'to lead us'), and strongly favoured in profession titles followed by person names (e.g. dottor (*?e) Rossi 'Dr. Rossi'), within lexicalised idioms (a maggior (*?e) ragione 'all the more likely') and within phrasal compounds (calor (*?e) bianco 'white heat'). It may optionally appear in certain verbal forms, such as infinitives or the present tense $3 \mathrm{sg}$ form of volere 'to want': cf. finir (e) male 'to end-up badly', vuol(e) partire 's/he wants to leave'. Troncamento of /o/ (once a regular feature) persists in FI in non-oxytonic 3pl. verb forms, although it is felt as old-fashioned (archaic or poetic) in SI: e.g. vivon(o) tutti '(they) all live', SI ['vi:vono 'tutii] vs. FI ['vi:von 'tutii], prendon(o) parte '(they) take part', SI ['prendono 'parte] vs. FI ['prendom 'parte].

The diphthongisation process that turned most $/ \varepsilon \mathrm{\rho} /$ in open syllables into /je wo/ (e.g. tiene ['tje:ne] 'keeps', fuoco ['fwo:ko] 'fire') is no longer productive, and its morpholexical distribution, while conditioned by morphological factors, most notably in verb inflection (Maiden 1992), is not phonologically predictable due to analogical levelling.

\section{Syllable structure and phonotactic constraints}

Syllable structure is relatively simple, at least in the autochthonous lexicon. (See e.g. Schmid 1999: 157-172 for a recent overview of phonotactic constraints obtaining in Italian.) In keeping with a typological universal, the coda position undergoes the most severe constraints, as it normally consists of just one of the following consonants: / $1 \mathrm{~N} \mathrm{~S}$ / (where capital letters indicate place and voicing neutralisation, respectively; as for $/ \mathrm{S} /$, in particular, see below for further details). Alternatively, the coda may consist of the first part of a distinctive or 'intrinsic' geminate. Other coda consonants occur only in loan-words, most of them originally drawn from Greek: e.g. ritmo /'rit.mo/ 'rhythm', nafta /'naf.ta/ 'Diesel oil'. Biconsonantal codas are quite rare, and restricted to learned words, such as transfrastico /trans.'frastiko/ 'trans-sentential'. The first part of a geminate may never belong to a complex coda (thus: $* / \mathrm{C}_{\mathrm{y}} \mathrm{C}_{\mathrm{x}} \cdot \mathrm{C}_{\mathrm{x}} /$ ).

Most treatments of Italian phonology suggest that $/ \mathrm{S} /+\mathrm{C}$ clusters are heterosyllabic. Historical data support this, as shown by the fact that open syllable diphthongisation of Proto-Romance / $/ /$ and $/ \varepsilon /$ was blocked before such clusters: tosto ['tosto] 'hard', vesti ['vesti] 'clothes' vs. cuore ['kworre] 'heart', viene ['vjeme] 'come.3sg'. Word-initially, /S/+C clusters must also have been heterosyllabic, with a tendency for /S/ to resyllabify as coda to a preceding syllable nucleus, as testified by the occurrence of $i$-prosthesis in Old Italian: con isforzo 'with effort', in Ispagna 'in Spain'. Another piece of evidence often invoked in this connection is the fact that word-initial $/ \mathrm{S} /+\mathrm{C}$ clusters prevented the replacement of the original definite article lo through $i l$, just like initial 'intrinsic' geminates (see above): cf. lo sparo 'the shot', lo scontro 'the crash' (cf. *il sparo, etc.). While heterosyllabicity is beyond any doubt for Old Italian, that a change may have occurred is evidenced by the fading of $i$-prosthesis (except in FI, where it marginally survives). Nowadays these clusters are mostly tolerated (see con sforzo, in Spagna), despite retention of epenthesis in frozen idioms such as per iscritto 'in written form'. A strictly heterosyllabic analysis would force us to assume a biconsonantal coda ([kons.'for.tso]), but this, as noted above, is highly marked (as an alternative, FI and RI speakers may optionally exhibit cluster simplification, as in [ko s'fortso]). A possible solution would be that the syllabification of $/ \mathrm{S} /+\mathrm{C}$ clusters is underdetermined for contemporary 
Table 3 Palatals and affricates' distribution after coda consonants.

\begin{tabular}{|c|c|c|c|c|c|c|c|}
\hline & $\kappa$ & $\mathrm{n}$ & $\int$ & ts & $\widehat{d z}$ & t] & $\sqrt{d_{3}}$ \\
\hline$r_{-}$ & $\begin{array}{c}(-) \\
\text { dar| }\{\rfloor i \\
\text { 'to give him' }\end{array}$ & $\begin{array}{c}(-) \\
\text { Garln lano } \\
\text { a place name }\end{array}$ & $\begin{array}{c}(-) \\
\text { Mart \lano } \\
\text { a place name } \\
\end{array}$ & $\begin{array}{c}+ \\
\operatorname{mar}[\hat{\mathrm{ts}}] \mathrm{o} \\
\text { 'March' }\end{array}$ & $\begin{array}{c}+ \\
\operatorname{ar}|\overline{d z}| i l l o \\
\text { 'brisk' }\end{array}$ & $\begin{array}{c}+ \\
\operatorname{mar}[\widehat{\mathrm{t}}]\rfloor o \\
\text { 'rotten' }\end{array}$ & $\begin{array}{c}+ \\
\text { arld̄ंlento } \\
\text { 'silver' }\end{array}$ \\
\hline $1_{-}$ & - & - & $\begin{array}{c}(-) \\
\text { Vol[[]]i } \\
\cdot \text { Volsci' }\end{array}$ & $\begin{array}{c}+ \\
\text { mil[ț] } a \\
\text { 'spleen' }\end{array}$ & $\begin{array}{c}+ \\
\text { el[रुz] leviro } \\
\text { 'newspaper } \\
\text { literary } \\
\text { article' }\end{array}$ & $\begin{array}{c}+ \\
\text { fal[t]le } \\
\text { 'sickle' }\end{array}$ & 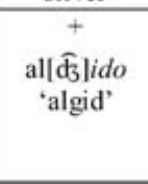 \\
\hline $\mathrm{n}_{-}$ & - & - & $\begin{array}{c}(-) \\
\text { con }|5| \text { lo } \\
\text { 'conscious' }\end{array}$ & $\begin{array}{c}+ \\
\text { can| |̇̂lone } \\
\text { 'song' }\end{array}$ & $\begin{array}{c}+ \\
\begin{array}{c}\operatorname{man}|\hat{\mathrm{d}}| o \\
\text { 'beef }\end{array}\end{array}$ & $\begin{array}{c}+ \\
\text { pan|ît } \mid a \\
\text { 'belly' }\end{array}$ & $\begin{array}{c}+ \\
\text { man|dु } \\
\text { 'to eare }\end{array}$ \\
\hline$s_{-}$ & - & - & - & - & - & - & $\begin{array}{c}(-) \\
\text { dis|䄧lelo } \\
\text { 'thaw' }\end{array}$ \\
\hline
\end{tabular}

speakers (Bertinetto 1999a, 2004). The actual probability of the hetero- vs. tautosyllabic solution varies according to the context and the idiosyncratic behaviour of the speakers (cf. Turchi \& Bertinetto 2000).

The onset position is far less constrained, as it may contain any consonant. However, some syntagmatic restrictions do exist. Glides may not exhaust the onset position if a consonant precedes, for in $/ \mathrm{VCjV} /$ and $/ \mathrm{VCwV} /$ strings the syllable boundary obligatorily precedes the $\mathrm{C}$. The range of conceivable combinations of coda + onset is further restricted, as palatals and affricates are subject to specific constraints. This is shown in table 3 . Rare combinations, possibly occurring only across a morpheme boundary, are marked with ' $(-)$ '. The sequence /s $\widehat{\mathrm{t}} /$ may optionally (and indeed regularly in MI) occur wordinitially in words like scentrato 'off centre' and scervellato 'brainless', where the FI pronunciation is mandatorily [J]entrato. After sonorant codas, affricates are unconstrained whereas $/ \mathrm{J} /$ and the sonorant palatals scarcely occur, apart from a few learned words $\left(/ 1 \mathrm{~J} /, / \mathrm{n} \int /\right)$, place names $\left(/ \mathrm{rn} /, / \mathrm{r} \int /\right)$, or in postlexical verb plus clitic sequences $(/ \mathrm{r} \kappa /)$.

Complex onsets typically arise from the combination of obstruents and $/ \mathrm{r} 1 \mathrm{j} \mathrm{w} /$, although not all sequences are allowed (e.g. */tl/). Combinations other than the above-mentioned occur only in learned loan-words from Ancient Greek, such as tmesi ['tme:zi] 'tmesis'. As exemplified above, the first position of a complex onset may be filled by (the second part of) a distinctive geminate consonant under certain conditions. 'Intrinsic' geminates, on the other hand, undergo more severe restrictions, as do palatal affricates. They cannot be followed by $/ \mathrm{r} 1 /$; as for glides, they are shown in table 4 . As may be seen, $/ \mathrm{ts} /$ and $/ \widehat{\mathrm{dz}} /$ are the only consonants in this set to combine with a following glide, albeit rarely. The remaining examples of $/ \mathrm{Cw} /$ only occur in archaic variants of words whose diphthongs have been simplified in modern Italian. Word-initially, triconsonantal strings may be found when $/ \mathrm{S} /$ is added to a

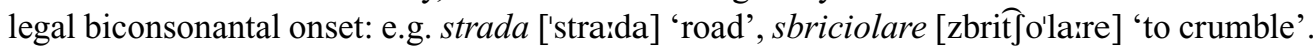

Nuclei may consist of a single vowel or a diphthong. Closing diphthongs can be represented as complex rhymes in a uniform manner (Marotta 1988). Opening diphthongs, on the other hand, do not display a uniform distribution. In masculine singular words, wordinitial strings of $/ \mathrm{j} /+$ vowel and $/ \mathrm{w} /+$ non-back vowel require one of the two preconsonantal allomorphs of the definite article: e.g. lo iodio 'the iodine', lo iato 'the hiatus', lo iettatore 'the bearer of ill-luck' vs. il whisky 'the whisky.', il uadi 'the wadi' (lo uadi is also admitted by some speakers). The prevocalic allomorph is only selected by patrimonial words beginning with /wo/: l'uomo 'the man', l'uovo 'the egg', like l'oro 'the gold' and l'oste 'the inn-keeper'. This has led some scholars to single out/wo/ from the other opening diphthongs, representing 
Table 4 Palatals and affricates' distribution before glides.

\begin{tabular}{|c|c|c|c|c|c|c|c|}
\hline & $\kappa$ & $\mathrm{n}$ & $\int$ & ts & $\widehat{\mathrm{d} z}$ & t] & $\widehat{d} 3$ \\
\hline$-\mathrm{j}$ & - & - & - & $\begin{array}{c}+ \\
a \mid \text { Eslione } \\
\text { 'action' }\end{array}$ & - & - & - \\
\hline$-w$ & $\begin{array}{c}(-) \\
f i[\kappa:](u) \text { olo } \\
\text { 'son' }\end{array}$ & $\begin{array}{c}(-) \\
\text { gra[s:l](u)ola } \\
\text { 'shower } \\
\text { (of blows)' }\end{array}$ & - & $\begin{array}{c}+ \\
\text { ca[ts] }{ }^{\prime} \text { uola } \\
\text { 'trowel' }\end{array}$ & 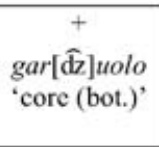 & $\begin{array}{c}(-) \\
l a \mid \hat{t}] \mid(u) \text { olo } \\
\text { 'small lace' }\end{array}$ & $\begin{array}{c}(-) \\
f a\left[\widehat{d}_{3}\right](u) o l o \\
\text { 'bean' }\end{array}$ \\
\hline
\end{tabular}

it as a complex nucleus, whilst in the remaining diphthongs the glide is syllabified as onset. Note, however, that recent loans with initial /wo/ select the preconsonantal allomorph: e.g. il walkie-talkie [il 'wolki 'tolki] 'the walkie-talkie'.

In SI, word and morpheme boundaries do not categorically constrain syllabification, as opposed to languages like English or German. Thus, Italian presents resyllabification, both derivationally (cf. inabile [i.'nai.bi.le] 'unable') and postlexically (cf. con Alberto [ko.n al.'ber.to] 'with Albert'). However, metalinguistic consciousness of morphological boundaries may induce educated speakers to perceive contrasts in syllabification such as the one between sublime [su.'bli.me] 'sublime' and subliminale [sub.li.mi.'na:.le] 'subliminal'. Since consonant-final words are rare in the native lexicon (although nowadays steeply growing in number due to borrowing), in post-lexical syllabification they are adjusted through gemination of their final consonant, so that this becomes ambisyllabic: cf. tram azzurro ['tram: a'dizuro] 'blue tramway', sub atletico ['sub: a'tle:tiko] 'athletic scuba diver', lapis appuntito ['la:pis: aprun'titto] 'sharpened pencil'. It should be noted, though, that in the latter case post-lexical resyllabification is preferred by some speakers, particularly by MI speakers (e.g. ['lai.pi.sap.iun.'ti..to]) (Camilli \& Fiorelli 1965: 154). The difficulty traditionally caused by word-final consonants is in any case accommodated in rural FI and RI pronunciations by using epenthesis before consonant or pause, e.g. ['tram:e], ['subse] and ['lapisse].

\section{Prosody}

Lexical stress is distinctive: fatico ['fartiko] 'phatic', fatico [fa'tiko] 'labour.1sg', faticò [fati'ko] 'laboured.3sg'. In the orthography, only final stress is marked, although attempts at also marking antepenultimate stress have repeatedly, and unsuccessfully, been put forth. Stress occurs on one of the last three syllables of the (lexical) word. In verb inflection, fourth-fromlast stress occurs in the 3rd person plural of the present tense of verbs with proparoxytonic root: abitano ['a:bitano] 'inhabit.3pl'. Postlexically, fourth- and even fifth- and sixth-from-last stress is found when the verb hosts one or more clitics, as these do not alter the stress position: mandaglielo ['mandaאielo] 'send it to him', macinamelo ['mait [inamelo] 'grind it for me', macinamicelo ['mait $\int$ inamitjelo] 'grind it for me onto it'. When stress retracts further back than the antepenult, the unmarked pronunciation of the following string is fully unstressed. Under emphasis, secondary rhythmic stress may never be inserted on the penult: abitano ['a:bita,no]/*['a:bitano] 'inhabit.3pl', mandaglielo ['mandaאie,lo]/*['manda,Kielo] 'send it to him'.

A phonological constraint dictates that a closed penult obligatorily carries stress (compatto [kom'pato] 'compact', esperto [es'perto] 'expert'), and this extends to internal /S/+C clusters ([kom'posto] 'composed'), which unequivocally shows that historically these clusters were heterosyllabic, however they are to be analysed synchronically. Actually, a handful of lexical 
exceptions are to be found in ancient loanwords (e.g. polizza ['politisa] '(insurance) policy', mandorla ['mandorla] 'almond', both of Greek origin) and in a few place-names (e.g. Taranto ['ta:ranto], Lepanto ['le:panto]), with the addition of sporadic modern loan-words such as liberty ['libberti] 'a type of architectural style', contrasting with liberti [li'berti] 'freed slaves'. While the heavy-penult constraint is still active to some extent, as witnessed by the current popular (mis)pronunciation of foreign words such as German Reisende [rai'zende] 'traveller(s)' or Forschungen [for'Jungen] 'research.pl', a minor stress-pattern is presently gaining ground, implying proparoxytonic stress on English-sounding words (especially, but not only, commercial labels), such as Benetton ['benetion] or Mediaset ['me:djaset] (firm names). This minor stress rule implies that the ultima be heavy, while it is insensitive to the weight of the penultima, as testified by Fininvest ['finimvest] (firm name). Until a few decades ago, the standard stress pattern in all these cases would have been oxytonic. The innovatory proparoxytonic stress pattern is nowadays enforced quite independently from the original stress of the loan in the donor language; this is to be seen both in the widespread (mis)pronunciation of English performance, currently stressed ['performans] even by some educated people, and in the above quoted firm name Benetton, which is actually an oxytonic family name from Veneto ([bene'tion]).

Secondary stress is not distinctive: there are no segmentally identical minimal pairs distinguished by the respective placement of primary vs. secondary stress (as opposed to Germ. úmlàufen ['vm,laofən] 'to run over (on foot)' vs. ùmláufen [,rm'laofən] 'to run around'). However, when word sequences are taken into consideration, one may marginally find oppositions such as attàccapánni [a,trakıa'panii] 'dress-hanger' vs. attácca pánni [a'trak:a 'panii] 's/he hangs clothes', although this phonetic contrast is more virtual than real, since all (non-emphasised) primary stresses but the utterance-final one are considerably weakened in the speech chain (Bertinetto 1981). As already suggested by attàccapánni, mentioned above, secondary stress is lexically determined in compounds: àpriscátole 'can opener', càpostazióne 'station-master', tèmperamatite 'pencil-sharpener', i.e. it falls on the syllable that would carry the primary stress in the corresponding isolated words. This accounts for the non-application of raising in e.g. tostapane (see above). Note however that the perceptual salience of secondary prominences tends to increase with the length of the inter-stress interval, for they are often barely noticeable as the interval grows less.

As for non-compound polysyllables, secondary prominences (in this case more properly called 'rhythmical' prominences), besides obeying the same prosodic constraint in terms of salience, tend to be movable, i.e. may be differently located depending on the rhythmical structure of the intonational phrase, provided the minimal distance of one intervening unstressed syllable is respected. Thus, depending on tempo and rhythmical context, a word such as lubrificatoio 'lubricator' may be produced in not less than three ways: lubrificatóio, lùbrificatóio, or, under special emphasis, lùbrifícatóio. As the example shows, the number of rhythmical prominences may vary. Considering this fair amount of variability, both in number and location of rhythmical prominences, the secondary stress marked in the transcriptions of the non-compound polysyllables quoted in this paper should not be taken as a categorical indication. There is however a general tendency not to shift the 'rhythmical' secondary stress to the immediate right of the syllable stressed on the preceding cycle, so that praticaménte sounds awkward as opposed to pràticaménte. But the whole matter still deserves more careful investigation.

In terms of prosodic typology, Italian is a syllable-timed language (cf. Bertinetto 1981, 1989). In particular, reduction of unstressed vowels is not found as a phonological process, so that their centralisation in connected speech, although measurably present (Albano Leoni et al. 1995), does not exceed the level of physiological articulatory undershooting. Equally, the process of intersyllabic vowel coarticulation, although well-documented instrumentally, is not as consistent as in English in terms of direction of assimilation, nor as strictly correlated with the process of vowel shortening as a consequence of the number of vowels in the foot 
(Vayra \& Fowler 1992). Needless to say, the prosodic typology issue is very thorny, and cannot be done full justice here. We limit ourselves to stressing that (syllable and inter-stress) duration is but one side of the matter, not the whole story.

Due to the lack of phonological import of word and morpheme boundaries, Italian presents no prominent junctural phenomena (Bertinetto 1981). Thus, the following sequences are differentiated only in emphatic pronunciation: di versi 'of verses' vs. diversi 'diverse', al largo 'in the open sea' vs. allargo 'enlarge.1sg', con piacere 'with pleasure' vs. compiacere 'to please' (although in MI the nasal, realised as [n], does not assimilate in the first case), essere roso 'to be gnawed' and esser eroso 'to be eroded' (at least in RI and MI, where both sibilants are voiceless or, respectively, voiced, whereas in SI and FI one finds $r o[\mathrm{z}] o$ and ero $[\mathrm{s}] \mathrm{o}$ ). On the other hand, pairs like li imitano 'imitate. $3 \mathrm{pl}$ them' and limitano 'limit.3pl' may be confused only in allegro speech, if the vowels at the word-boundary coalesce.

Except for the contrast between the major illocutionary functions - declarative sentences, continuative clauses, global (i.e. polar) and partial questions - intonation is used to convey pragmatic intentions, according to regionally-connotated schemes. Indeed, the different intonational patterns are a major discriminant of local varieties (Canepari 1979, Endo \& Bertinetto 1997). Limiting our consideration to the most salient features and to pragmatically neutral contexts, the last stressed syllable presents falling $\mathrm{F}_{0}$ contour in declarative sentences, falling-rising or rising-falling contour in continuative clauses, falling contour followed by a steep rise in polar questions. As for partial questions, they present initial rise, located on the stressed syllable of the $w h$-word, while the overall contour is characterised by gradual fall or (less often) by final rise (Magno Caldognetto et al. 1978). Contrastive focus may be realised on any syntactic component, and is manifested by a sharp rising-falling contour on the stressed syllable, as well as by an increase in duration and amplitude. For a recent overview of the literature on Italian intonation, cf. D’Imperio (2002), Avesani \& Vayra (2003), Gili Fivela \& Savino (2003).

\section{Transcription of sample passage}

Under SI we provide a very formal pronunciation (almost a word level one); under 'SI-allegro style' we propose instead a possible fluent version of the same passage. FI, RI and MI, referring to the three local varieties considered in this paper, are conceived in the same vein as SI (i.e. without taking into account allegro style processes). It will not go unnoticed that FI and RI - as compared to MI - present greater morpholexical idiosyncrasy.

The sources of our transcriptions were recordings by native speakers of the four varieties considered. However, in order to provide a more informative rendering, we did not transcribe purely idiosyncratic features. Furthermore, we slightly elaborated the FI and RI transcriptions, in order to provide more information as for these varieties. Indeed, when spoken by educated people, FI and RI may sound very close to SI (which, as noted above, is Florentine-based); and this is definitely likely to occur while reading a passage into a microphone. As a consequence of our elaboration, the FI and RI transcriptions present greater morpholexical divergence from SI as compared to MI. They reflect the behaviour of relatively educated speakers who do not want (or possibly are unable) to make a conscious effort to sound 'standard'. Note, however, that although even more strongly local features would emerge as one approaches the other end of the continuum (i.e. the vernacular), our transcriptions by no means imply that all speakers in Florence and Rome adopt the illustrated behaviour, nor that MI sounds in general more SI-like, at least at the morpholexical level, than FI and RI.

Our choice has a historical background. The variety of Italian spoken in Florence is the result of the uninterrupted spontaneous evolution of the language (which went even further in the local basilect, unconstrained by literary codification), and this indirectly extends to Rome, 
since Roman speech was heavily tuscanised in the late Middle Ages. It is crucial to realise that this process of tuscanisation reached the most basilectal varieties, to the point that the original Italo-Romance vernacular, which shared many isoglosses with southern Italian dialects, was ousted by a tuscanised one. As a result of these historical circumstances, in both Florence and Rome one observes a real continuum between vernacular and SI. By contrast, in Milan a sharper distinction is to be observed between the two. MI reflects the peculiar adaptation of the literary standard, which was for a long time totally alien to uneducated speakers (hence, the large majority of the population) and did not influence the local vernacular (Milanese) as heavily as it did in Rome. Thus, on the one hand, the Milanese vernacular is in all respects extremely remote from SI, while, on the other hand, MI is phoneticswise distinctly different from SI. Indeed, a speaker of MI is not likely to adopt the SI pronunciation, unless s/he has received explicit training (e.g. for professional purposes).

One further remark concerns the notation of stress on syllables beginning with the second part of a geminate. Although the current IPA convention requires it to be marked as e.g. pattume [pa'tu:me] 'trash', one might also choose to transcribe [pat'uime], to convey the (phonologically relevant) information that the geminate forms both the coda of the preceding syllable and the onset of the following one.

The realisation of intervocalic /s/ vs. /z/ constitutes a delicate point, for lexicallyconditioned change seems to be in process under northern influence. Since our speaker belongs to the younger generation, in the allegro style recording [z] shows up in a few cases where [s] would normally be used by the older generation. Thus, the speaker realised ripo[z]arsi, line 7, ripo[z]atasi, line 9, and rispo[z]e, line 11 .

Note finally that the hypercultivated pronunciation of the word Borea (conforming to the Greek, rather than to the Latin stress rules) would imply stress on the second vowel. The most widespread pronunciation, however, which our speakers adopt and most dictionaries report, presents stress retraction.

The recordings are available at $<$ http://alphalinguistica.sns.it/Archivio.htm $>$.

\section{SI}

la 'borrea e il fa'vornio \|

una 'volta | alia 'borrea 'venie 'voKia di 'prennder ma'rito $\|$ an'do dial fa'vornio e Kii 'disse | 'vwoi 'Es:ere ,mi'o 'spo:zo \|| il fa'vornio ' $\varepsilon$ :ra un 'tipo ata'kaato ai kwa'trimi |

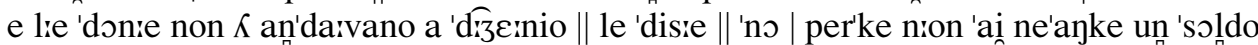
di 'dorte || la 'borrea |'punta sul 'virvo | si 'mirze a sio'f:jarre kon 'tute le , su'e 'fortse || so'f:jo

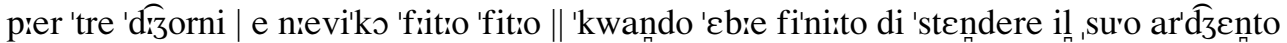
in'torno | 'disse || 'Eksoti la 'mia 'dorte | 'tu kre dii't ervi ke nıon' $\widehat{\text { tje }} 1$ 'o || e an'do a ripo'sarsi delia fa'tikka || il fa'vonnio skro'lı lie 'spalie | e si 'mizze a sıo'f:jarre 'lui $\|$ la kam'pania e i 'monti res'ta:rono 'sotio um 'fja:to 'kaldo ke 'frolse fin 1 'ultimo 'fjok:o di 'neive || la 'borrea | ripo'sa:tasi per 'be:ne | 'vi:de ke 'drelia 'dorte non res'ta:va 'pju

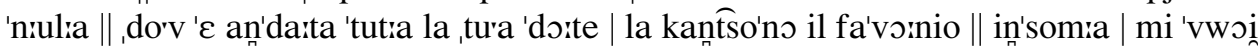
aj'ko:ra per ma'rito \|| la 'borrea Kii ris'porse || 'no | 'nom vo'rrei 'ma:i 'Esiere, tu'a

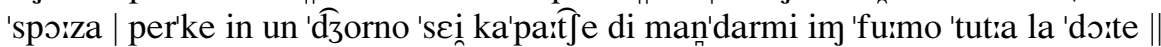

\section{SI-allegro style}

la 'borrea e il fa'vornjo \|

una 'volta | alia 'borrea 'ven:e 'voKia di 'prender ma'ri:to \| an'do dial fa'vo:njo e Kii 'disie $\|$ ,vwoi 'Es:ere mjo 'spo:zo || il fa'vornjo era un 'tipo at:a'ksato ai kwa'trimi |

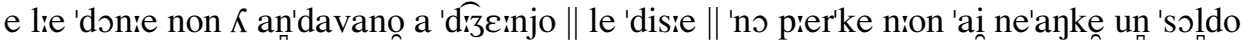
di 'dərte || la 'borrea |'punta sul 'virvo| si 'mize a sco'frjare kon 'tute le swe 'fortse $\|$ so'frjo

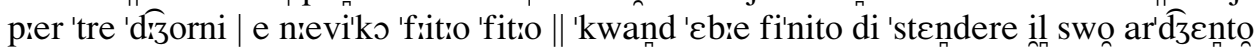


in'torno | 'disse || 'Eksoti la mja 'dorte | 'tu kse dri't a ripo'sarsi delia fa'tika || il fa'vonjo skro'lı lie 'spalie | e sii 'mi:ze a sı'f́fijare 'luii || la kam'pania e i 'monti res'ta:rono 'sotro um 'fjato 'kaldo ke 'frolse fin 1 'ultimo 'fjok:o di 'ne:ve || la 'borrea | ripo'satasi per 'be:ne | 'vide ke 'dielia 'dorte non res'ta:va 'pju 'n:ulia || 'dorv $\varepsilon$ an'da:ta 'tutra la twa 'dorte | la kañtso'no inl fa'vornjo || in'somia | mi 'vwoj aj'ko:ra per ma'rito \| la 'borrea Kii ris'poise || 'no | nom vo'rici 'mai ' $\varepsilon s$ ere twa

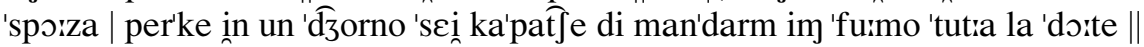

\section{FI}

NOTE. One may characterise the FI transcription below as somehow mesolectal, as compared with MI (but see also RI). This will show how FI may diverge from SI, despite being so close to it. It should be noted that the lenition process affecting intervocalic voiceless stops (unless they undergo gemination as a consequence of 'raddoppiamento') is fairly categoric for $/ \mathrm{k} / \rightarrow[\mathrm{h}]$, less so for $/ \mathrm{p} \mathrm{t} \rightarrow[\phi \theta]$. Consider, for instance, ['dorte] (line 6), as opposed to ['do: $\theta$ e] (lines 4 and 12). In a few other cases our recording does not present lenition, but we marked it in the transcription to suggest that it would be perfectly legitimate (cf. fini $[\mathrm{t}] o$, line 5, fa[t] ica, line 7, [t] ua, line 11). By contrast, we chose not to mark the similar lenition process affecting intervocalic voiced stops, because it seems to be even less consistent. The reader should be aware, however, that intervocalic non-geminated [b d g] may alternate with their

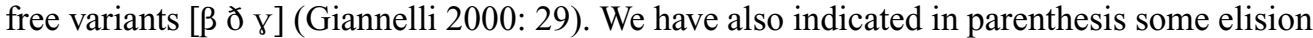
processes that seem to be fairly typical of this variety, even in non-allegro style (Agostiniani 1989). In the recording of our sample passage, however, our informant did not always apply this process: he read, e.g., ['nom vo'rici 'mai 'Esiere] (line 11). We have also indicated in square brackets two cases of obligatory insertion (limited to this variety) of the article before the possessive adjective. Note, finally, that since our speaker belongs to the younger generation, he had [z] instead of [s] in the same words where this occurs in SI-allegro style: ripo[z]arsi, line 7 , ripo[z]atasi, line 9, and rispo[z]e, line 11.

Other phonological processes (not reflected in the transcription below) are typical for Florentine speech at a more basilectal level. Most notably, a sandhi assimilation process affecting final $/ 1 /$ in the det.m.sg. article $i l$ (also when fused with prepositions). For instance: $i l$ favonio $\rightarrow i[\mathrm{f}:]$ avonio, dal favonio $\rightarrow d a[\mathrm{jf}:]$ avonio, sul vivo $s u[\mathrm{jv}:]$ ivo. Equally, in the basilect we would find the following (morpholexically conditioned) assimilations concerning $[\mathrm{r}]$ in coda position: per tre [pe 'trre], per marito [pe ma'ri:Өo], mandarmi [mañ'dami], riposarsi [riфo'sasii].

la 'borrea e il fa'vornio \| una 'volta | alia 'borrea 'ven:e 'vऽKia di 'prennder ma'ri:Өo $\|$ añ do dial fa'vornio e Kii 'disie $\|$

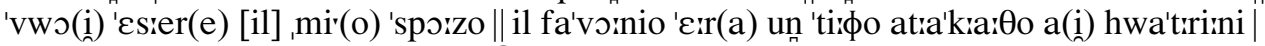

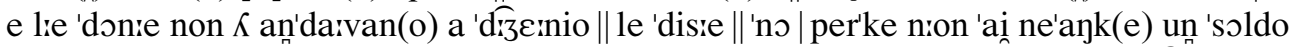
di 'do:Өe || la 'borrea |'punta sul 'virvo | si 'mizz(e) a sio'f:jaire hon 'tut:e le ,su'(e) 'fortse || so'f:jo

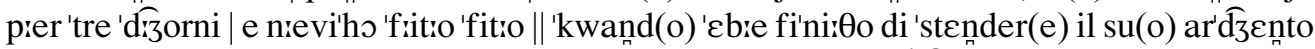

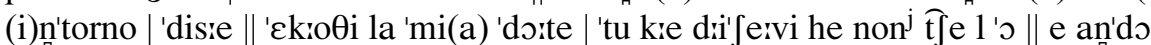

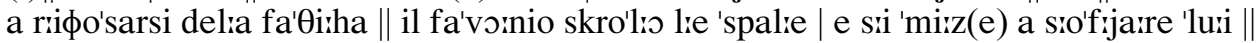
la ham'papra e (i) 'monti res'tarrono 'sot:(o) um 'fja:Өo 'haldo he ' frolse fin 1 'ultimo 'fjokıo

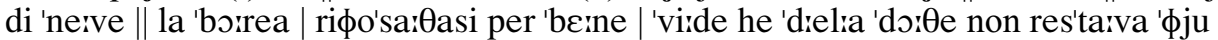
'n:ulia \|, do’v ' $\varepsilon$ an'dar $\theta$ a ' $\theta$ utra la,$\theta u$ '(a) 'dor $\theta \mathrm{e} \mid$ la hantso'no il fa'vornio $\|$ in'soma | mi 'vwo(i)

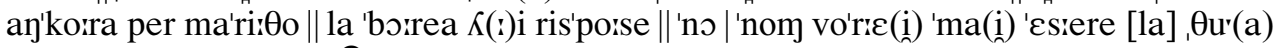

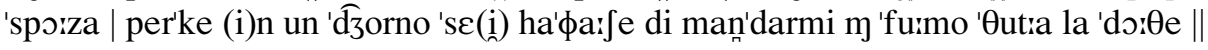




\section{RI}

NOTE. Also in this case, our transcription abstracts away from performance idiosyncrasies. Thus, we regularly transcribed intervocalic stop lenition, characteristic of RI connected speech, although our informant did not consistently apply it in the sample passage. Suppression of the process is particularly likely to occur in utterance-final position: e.g. [man'darm im 'furmo 'dutia la 'dorte] (line 12). Although we marked this process only on stops, it may also affect voiceless fricatives. In our sample recording, we found the following pronunciations: [e le, swe 'vortse] (line 4), [ripo'za:dasi per 'beine] (line 7). Note that SI [K:] occurs in our recording, instead of expected RI [j:], in e.g. ['voKia] (line 1). Conversely, our transcription does not reflect a markedly basilectal process, which our informant sometimes applied, consisting

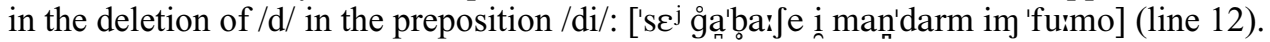

la 'bısrea e il fa'vornjo \|

una 'volta | ala 'brorrea 'vence 'vojia di 'brenndere ma'ri:do \| an'do dal fa'vornjo e jii 'disse || 'vwoi 'Es:ere ,mjo 'sporso || il fa'vornjo 'E:ra un 'tisbo at:a'k:a:do ai g̊wa'trinini | e le 'donse non ji añ'darvano a 'dizernjo || le 'disse || 'no | per'ke non 'ai ne'ajke un 'tsoldo di 'dorde || la 'brorrea |'bunta sul 'virvo | si 'misse a sı'frjarre kon 'tut:e le swe 'fortse || so'fijo

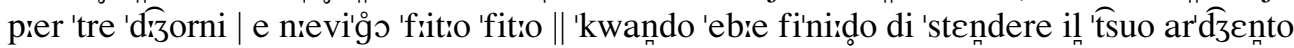

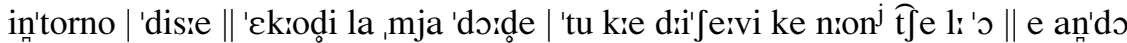
a ripo'sartsi dala fa'dirg̊a || il fa'vornjo skro'lı lee 'spalie | e sii 'misse a sio'fijarre 'luii || la g̊am'panza e i 'monti res'tarrono 'sotro um 'fja:do 'g̊aldo ke ' 'oltse fin ${ }^{\circ} 1$ 'ultimo 'fjok:o di 'ne:ve || la 'brorrea | ripo'sa:dasi per 'be:ne | 'vi:de ke 'drela 'dorde no res'tarva 'bju 'nulia || , do’v ' $\varepsilon$ an'da:da 'dutra la dwa 'dorde | la g̊antso'no il fa'vornjo || in'tsoma | mi 'vwori aj'korra per ma'riido \|| la 'bısrea jii ris'posse || 'no | 'nom vo'rei 'mai 'esiere ,dwa

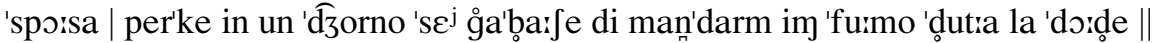

\section{MI}

NOTE. Also in this case, we did not stick to performance idiosyncrasies. In fact, our speaker did not always produce a velar nasal in coda position; accordingly, she had [non t $\int \mathrm{e} 1$ 'o], line 6, [fin 1 'ultimo], line 8, and [nõ' res'ta:va], line 9. Likewise, she uttered SI ['E:ra] (line 2) for MI ['e:ra]. In addition, she pronounced [vwoi ' $\varepsilon$ siere] (line 2) alongside ['vwoi an'korra] (lines 10-11), possibly as a result of partial destressing. At a more general level, it should be observed that geminate consonants are less prominent in the Northern varieties of Italian than in SI or in Central and Southern varieties, and are indeed absent in the basilect. Although our MI speaker produced gemination, it is altogether less salient than in the remaining recordings. Note, finally, that MI /e/, and even more $/ \varepsilon /$, are slightly lowered, although we did not mark this detail in the transcription.

la 'borrea e il fa'vərnjo \| una 'volta | alia 'borrea 'venie 'və:Ka di 'prennder ma'ritto || añ'do dal fa'vərnjo e Ki 'disie $\|$ 'vwoi 'essere ,mi'o 'spo:zo || il fa'vonno 'erra un 'tipo atra'kıa:to ai kwa'trimi | e le 'donie non $K i$ añ'davano a 'ḑe:nio || le 'disie || 'no | per'ke non 'ai ne'ajke un 'soldo di 'dorte || la 'borrea | 'punta sul 'virvo | si 'mizze a so'frjarre kon 'tute le, su'e 'fortse || so'frjo

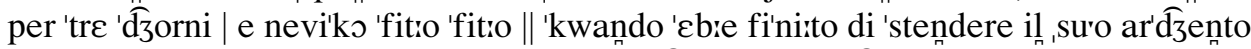

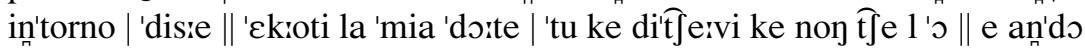
a ripo'zarsi dalia fa'tika || il fa'vornjo skro'lı le 'spalie | e si 'mi:ze a so'fijarre 'luii || la kam'pania e i 'monti res'tarono 'sotio un 'fja:to 'kalno ke 'folse fin 1 'ultimo 'fjok:o di 'ne:ve || la 'borrea | ripo'zatasi per be:ne | 'virde ke 'delia 'dorte non res'tarva 'pju

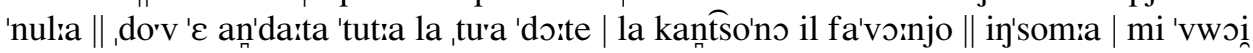
aj'korra per ma'ritto || la 'borrea Ki ris'po:ze || 'no | 'non vo'rici 'mai ' 'Esiere, tu'a

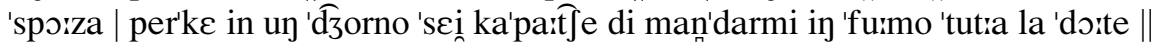




\section{Orthographic version}

NOTE. The text stems, with a few modifications, from the Collection Fiabe Italiane, edited by Italo Calvino. Essentially, it is a variant of the famous 'North wind and South wind' story. In one case we present an alternative between parenthesis; both versions are grammatical, and indeed our speakers used them both, as shown in the above transcriptions.

\section{La Borea e il Favonio}

Una volta alla Borea venne voglia di prender marito. Andò dal Favonio e gli disse:

- Vuoi essere il mio sposo? Il Favonio era un tipo attaccato ai quattrini

e le donne non gli andavano a genio. Le disse: - No, perché non hai neanche un soldo di dote. La Borea, punta sul vivo, si mise a soffiare con tutte le sue forze. Soffiò per tre giorni, e nevicò fitto fitto. Quando ebbe finito di stendere il suo argento intorno, disse: - Eccoti la mia dote, tu che dicevi che non ce l'ho! - e andò a riposarsi della (dalla) fatica. Il Favonio scrollò le spalle, e si mise a soffiare lui. La campagna e i monti restarono sotto un fiato caldo che sciolse fin l'ultimo fiocco di neve. La Borea, riposatasi per bene, vide che della dote non restava più nulla. - Dov'è andata tutta la tua dote? - la canzonò il Favonio. - Insomma, mi vuoi ancora per marito? La Borea gli rispose: - No, non vorrei mai essere tua sposa, perché in un giorno sei capace di mandarmi in fumo tutta la dote.

\section{Translation}

\section{Boreas and Favonius}

Once upon a time Boreas [the North Wind] felt like getting married. She went up to Favonius [the West Wind] and asked him, 'Would you like to be my husband?' Favonius was a stingy fellow and did not like women. He told her 'No, because you do not have a penny for your dowry.' Boreas, pierced to the quick, began to blow with all her might. She blew for three days, and it snowed heavily. As soon as she stopped spreading her silver all around, she said, 'Here is my dowry, you who said that I do not have any!' and she went to rest from her labor. Favonius shrugged, and he himself started to blow. The countryside and the mountains were caught under a warm breath that melted every last snowflake. Boreas, once she had completely recovered, saw that nothing was left of her dowry. 'Where has all your dowry gone?' Favonius mocked her. 'So, do you still want me as a husband?' Boreas replied: 'No, I would never be your wife, because in a day you can send all my dowry up in smoke.'

\section{Acknowledgements}

This paper was originally conceived as a usual IPA illustration sketch, upon invitation by the Editor. As work advanced, however, we felt it necessary to elaborate on it, especially so as to provide more information than usually done concerning regional vareties of Italian, which nowadays play a major role in the linguistic community. We wish to thank Peter Ladefoged for his encouragement to expand the original sketch, as well as for his (not only technical) help in drawing the vowel chart. We are also indebted to three anonymous referees, to John Esling, and to the following friends and colleagues for useful suggestions: Federico Albano Leoni, Marco Baroni, Walter Belardi, Silvia Calamai, $\dagger$ Arrigo Castellani, Amedeo De Dominicis, Edda Farnetani, Giovanna Marotta, Alberto Mioni, Diana Passino, Emanuele Saiu, Arianna Uguzzoni.

\section{References}

Abramson, A. S. (1986). The perception of word-initial consonant length: Pattani Malay. Journal of the International Phonetic Association 16, 8-16. 
AbSAlom, M., HaJeK, J. \& SteVens, M. (2004). Il fenomeno del raddoppiamento sintattico nella realtà linguistica italiana. In Albano Leoni, F., Cutugno, F., Pettorino, M. \& Savy, R. (eds.), Atti del convegno nazionale 'Il Parlato Italiano' - Napoli 13-15 febbraio 2003. Napoli: D'Auria (CD-Rom, text A01).

Agostiniani, L. (1989). Fenomenologia dell'elisione nel parlato in Toscana. Rivista Italiana di Dialettologia 13, 7-46.

Albano Leoni, F., Cutugno, F. \& SAVy, R. (1995). The vowel system of Italian connected speech. Proceedings of the International Congress of Phonetic Sciences, Stockholm (vol. 4), 396-399.

AVESANI, C. \& VAYRA, M. (2003). Broad, narrow and contrastive focus in Florentine Italian. In Proceedings of the 15th International Congress of Phonetic Sciences, Barcelona, 1803-1806.

BARONI, M. (2001). The representation of prefixed forms in the Italian lexicon: evidence from the distribution of intervocalic [s] and [z] in Northern Italian. In Booij, G. \& van Marle, Z. (eds.), Yearbook of Morphology 1999, 121-152. Dordrecht: Foris.

BERRUTO, G. (1987). Sociolinguistica dell'italiano contemporaneo. Roma: La Nuova Italia.

BERTINETTO, P. M. (1981). Strutture prosodiche dell'Italiano. Florence: Accademia della Crusca.

BERTINETTO, P. M. (1989). Reflections on the dichotomy 'stress- vs. syllable-timing'. Revue de Phonétique Appliquée 91/93, 99-130.

BertinetTo, P. M. (1999a). La sillabazione dei nessi /sC/ in italiano: un'eccezione alla tendenza 'universale'? In Benincà, P., Mioni, A. M. \& Vanelli, L. (eds.), Fonologia e morfologia. Atti del $31^{\circ}$ Congresso Internazionale SLI, 71-96. Rome: Bulzoni.

BERTINETTO, P. M. (1999b). Boundary strength and linguistic ecology (mostly exemplified on intervocalic /s/-voicing in Italian). Folia Linguistica 33, 267-286.

BertinetTo, P. M. (2004). On the undecidable syllabification of $/ \mathrm{sC} /$ clusters in Italian: Converging experimental evidence. Italian Journal of Linguistics 16, 349-372.

BERTINETTO, P. M. \& LOPORCARO, M. (1999). Geminate distintive in posizione iniziale: uno studio percettivo sul dialetto di Altamura (Bari). Annali della Scuola Normale Superiore di Pisa, serie IV, 4, 305-322.

CAMilli, A. \& Fiorelli, P. (1965). Pronuncia e grafia dell'italiano. Terza edizione riveduta a cura di Piero Fiorelli. Florence: Sansoni.

CANEPARI, L. (1979). Introduzione alla fonetica. Turin: Einaudi.

CANEPARI, L. (1980). Italiano standard e pronunce regionali. Padua: CLEUP.

CANEPARI, L. (1999). Manuale di pronuncia italiana. Bologna: Zanichelli.

CAssola, A. (1992). Malta. In Bruni, F. (ed.), L'italiano nelle regioni: Lingua nazionale e identità regionali, 861-874. Turin: UTET.

CAstellani, A. (1956). Fonotipi e fonemi in italiano. Studi di Filologia Italiana 14, 435-453. Revised edition in: Id., Saggi di linguistica e filologia italiana e romanza (1946-1976) (vol. I, 1980), 49-69. Roma: Salerno Editrice.

CASTELlani, A. (1993). Zeta per esse dopo liquida o nasale a Firenze? Studi Linguistici Italiani 19, 53-61.

CELATA, C. \& KAEPPELI, B. (to appear). Affricazione e rafforzamento in italiano: alcuni dati sperimentali.

COVERI, L. \& BETTONI, C. (1991). Italiano e dialetti italiani fuori d'Italia: Bibliografia. Siena: Scuola di lingua e cultura italiana per stranieri.

Dell'Aglio, M., Bertinetto, P. M. \& Agonigi, A. (2002). Le durate dei foni vocalici in rapporto al contesto nel parlato di locutori pisani. Primi risultati. In Regnicoli, A. (ed.), La fonetica acustica come strumento di analisi della variazione linguistica in Italia, 53-58. Rome: Il Calamo.

De MAURO, T. (1972). Storia linguistica dell'Italia unita. Bari: Laterza.

D'IMPERIO, M. (2002). Italian intonation: an overview and some questions. Probus 14, 37-69.

ENDO, R. \& BERTINETTO, P. M. (1997). Aspetti dell'intonazione in alcune varietà di italiano. In Cutugno, F. (ed.), Fonetica e fonologia degli stili dell'italiano parlato: Atti delle Settime Giornate di Studio del Gruppo di Fonetica Sperimentale (A.I.A.), 27-49. Roma: Collana degli Atti dell'Associazione Italiana di Acustica (vol. 24).

ENDO, R. \& BERTINETTO, P. M. (1999). Caratteristiche prosodiche delle così dette 'rafforzate' italiane. In Delmonte, R. \& Bristot, A. (eds.), Aspetti computazionali in fonetica, linguistica e didattica delle lingue: modelli e algoritmi. Atti delle None Giornate di Studio del Gruppo di Fonetica Sperimentale (A.I.A.), 243-255. Rome: Associazione Italiana di Acustica (vol. 26). 
Ferrero, F. (1972). Caratteristiche acustiche dei fonemi vocalici italiani. Parole e Metodi 3, 9-32.

Ferrero, F., Magno Caldognetto, E., Vagges, K. \& Lavagnoli, C. (1978). Some acoustic characteristics of the Italian vowels. Journal of Italian Linguistics 3, 87-95.

GALLI DE' PARATESI, N. (1985). Lingua toscana in bocca ambrosiana. Tendenze verso l'italiano standard: un'inchiesta sociolinguistica. Bologna: Il Mulino.

GianNelli, L. (2000). Toscana. Pisa: Pacini.

GiLi Fivela, B. \& SAVINo, M. (2003). Segments, syllables and tonal alignment: a study on two varieties of Italian. Proceedings of the International Conference of Phonetic Sciences, Barcellona, 2933-2936.

Hume, E., Müller, J. \& VAN Engelenhoven, A. (1997). Initial geminates in Leti: consequences for moraic theory. Studies in the Linguistic Sciences 27, 119-138.

LANDI, R. \& SAVY, R. (1996). Durata vocalica, struttura sillabica e velocità d'eloquio nel parlato connesso. In Atti del XXIV Convegno Nazionale (A.I.A.), 65-70.

LEPSCHY G. (1964). Note sulla fonematica italiana. L'Italia dialettale 27, 53-67.

LOPORCARO, M. (1996). On the analysis of geminates in Standard Italian and Italian dialects. In Hurch, B. \& Rhodes, R. (eds.), Natural Phonology: The State of the Art. Papers from the Bern Workshop on Natural Phonology, September 1989, 153-187. Berlin, New York \& Amsterdam: Mouton de Gruyter.

LOPORCARO, M. (1997). L'origine del raddoppiamento fonosintattico: Saggio di fonologia diacronica romanza. Basel \&Tübingen: Francke.

Magno Caldognetto, M., Ferrero, F., LAVAgnoli, C. \& VAGGes, K. (1978). F0 contours of statements, Yes-No questions and wh-questions of two varieties of Italian. Journal of Italian Linguistics 3, 57-68.

MAIDEN, M. (1992). Irregularity as a determinant of morphological change. Journal of Linguistics $\mathbf{2 8}$, 285-312.

MAIDEN, M. \& PARRY, M. (1997). The Dialects of Italy. London: Routledge.

MARAZZINI, C. (1994). La lingua italiana: Profilo storico. Bologna: Il Mulino.

MAROTTA, G. (1985). Modelli e misure ritmiche. La durata vocalica in italiano. Bologna: Zanichelli.

MarotTA, G. (1988). The Italian diphthongs and the autosegmental framework. In Bertinetto, P. M. \& Loporcaro, M. (eds.), Certamen Phonologicum: Papers from the 1987 Cortona Phonology Meeting, 399-430. Turin: Rosenberg \& Sellier.

MarottA, G. \& Sorianello, P. (1998). Vocali contigue a confine di parola. In Bertinetto, P. M. \& Cioni, L. (eds.), Unità fonetiche e fonologiche: Produzione e percezione. Atti delle $8^{e}$ Giornate di studio del Gruppo di Fonetica Sperimentale (A.I.A.), 101-113. Pisa: Scuola Normale Superiore.

MCCRARY, K. (2003). Reassessing the role of the syllable in Italian phonology: an experimental study of consonant cluster syllabification, definite article allomorphy and segment duration. Ph.D. dissertation, UCLA.

Metzeltin, M. (1992). La Dalmazia e l'Istria. In Bruni, F. (ed.), L'italiano nelle regioni. Lingua nazionale e indentità regionali, 316-335. Turin: UTET.

MigLIORINI, B. (1954). Editorial note on the article by R. Giacomelli (Le palatali sibilanti italiane e la loro trascrizione fonetica, pp. 76-84). Lingua Nostra 15, 84-85.

Mioni, A. M. (2001). Elementi di fonetica. Padova: Unipress.

MULJAČIĆ, ž. (1972). Fonologia della lingua italiana. Bologna: Zanichelli.

NESPOR, M. (1993). La fonologia. Bologna: Il Mulino.

Pellegrini, G. B. (1960). Tra lingua e dialetto in Italia. Studi Mediolatini e Volgari 8, 137-153. [Also in Pellegrini, G. B. (1975), Saggi di linguistica italiana: Storia, struttura e società, 11-54. Turin: Boringhieri.]

Pellegrini, G. B. (1977). Carta dei dialetti italiani. Pisa: Pacini.

Poggi SAlani, T. (1976). Note sull'italiano di Milano e in particolare sulla $e$ tonica. In Simone, R., Vignuzzi, U. \& Ruggiero, G. (eds.), Studi di fonetica e fonologia: Atti del Convegno Internazionale di Studi, Padova 1-2 ottobre 1973 (SLI 9), 245-260. Rome: Bulzoni.

RoHLFs, G. (1966-69). Grammatica storica della lingua italiana e dei suoi dialetti (3 vols.). Turin: Einaudi.

Romano, A. (2003). Geminate iniziali salentine: un contributo di fonetica strumentale alle ricerche sulla geminazione consonantica. In Caprini, R. (ed.), Parole romanze: Scritti per Michel Contini, 349-376. Alessandria: L'Orso. 
SCHMID, S. (1999). Fonetica e fonologia dell'italiano. Turin: Paravia.

SORIANELLO, P. (2003). Spectral characteristics of voiceless fricative consonants in Florentine Italian. In Proceedings of the 15th International Congress of Phonetic Sciences, 3081-3084. Barcelona.

TURCHI, L. \& BERTINETTO, P. M. (2000). La durata vocalica di fronte ai nessi /sC/: un'indagine su soggetti pisani. Studi Italiani di Linguistica Teorica e Applicata 29, 389-421.

VAYRA, M. \& FOWLER, C. (1992). Declination of supralaryngeal gestures in spoken Italian. Phonetica 49, $48-60$. 